\title{
Regulation and Protection of the Sea from Oil Pollution by Tanker Ships in Indonesia
}

\author{
Elly Kristiani Purwendah ${ }^{1 *}$, Aniek Periani ${ }^{1}$, Elisabet Pudyastiwi ${ }^{1}$ \\ 1 Universitas Wijayakusuma Purwokerto, Indonesia \\ *e-mail: elly_kristiani@yahoo.co.id
}

Article history: Received 15 December 2020; Accepted 31 March 2021; Available online 30 April 2021

\begin{abstract}
Environmental control in this case is intended to include prevention, mitigation and recovery carried out by the government, regional government and those in charge of businesses and/or activities in accordance with their respective authorities, roles and responsibilities. One of the instruments for preventing pollution and/or environmental damage consists of; environmental economic instruments, environmental-based laws and regulations, environmental-based budgets and other instruments according to the needs and/or developments of science.
\end{abstract}

\section{Keywords:}

Environment;

Environmental

Pollution; Marine Areas

Copyright @ Universitas Pendidikan Ganesha. All rights reserved.

\section{Introduction}

Indonesia's sea area which reaches 3.11 million $\mathrm{km} 2$ makes the potential of the marine sector invaluable (Siahaan, 2018), especially from its marine natural wealth sector. The potential of marine wealth is so important as prioritized by Indonesia in the concept of green economy and blue economy which leads to sustainable development, as conveyed by the President of the Republic of Indonesia during his remarks at the Rio +20 Conference (United Nations Conference on Sustainable Development) in Rio de Jeneiro, Brazil on 20-22 June 2012 (Lilley, 1999).

The marine environment is part of a country's economy. With a coastline of approximately $95,181 \mathrm{~km}$, Indonesian waters have high potential. This measure is second only to Canada as a country that has the second longest coastline in the world. The economic value of the sea is estimated at US \$ 3 trillion - US \$ 5 trillion or equivalent to Rp. 36,000 trillion - Rp. 60,000 trillion per year (Gore, 1995). This figure does not include other potentials that come from the wealth of biotechnology, marine tourism and marine transportation development. Indonesia's huge maritime potential is captured as one of the flagship visions and missions of President Jokowi's current administration. Apart from that, the great economic and ecological potential that is stored as a maritime country, the potential for natural damage that can be caused by excessive exploration which can threaten the sustainability of development should also receive attention. For this reason, the government is currently promoting maritime economic policies with a blue economy model. Basically, blue economy combines economic development and environmental preservation (Media Finance; 2015). 
Considering the very strategic role of the sea because some people rely on the sea for their livelihoods and livelihoods, the sea needs to receive major attention in law enforcement, especially from the impact of ecosystem damage due to pollution (Atmadja, 1992). Sources of marine pollution can come from: (1) pollution caused or originating from ships; (2) pollution originating from oil drilling installations; (3) sources of pollution on land; and (4) air pollution. The problem of oil pollution due to ship (tanker) accidents in Indonesia needs serious attention with regard to the right to sue (ius standi), evidence related to scientific verification to explain causal relationships, application of the principle of compensation, coverage and extent of environmental issues to determine the amount of compensation, and environmental restoration criteria related to the formal truth system adopted in the civil compensation prosecution system (Marsudi Triatmodjo, 2001).

In the period 2011-2015, there were 4 (four) oil contaminations in the Cilacap sea. In 2011 there were two cases of pollution in July and September by the Super Tanker Ship TT. Arenza XXVII and Ship MT. Medelin Atlas Belawan IMO 8717245, and in April 2012 the MV. Indo Baruna $\mathrm{V}$ is polluting the marine environment of Cilacap. Most recently in 2015 in May 2015 tanker ship MT. Martha Petrol. Demands for compensation for oil pollution by tankers in Cilacap sea were made by fishermen to PT. Pertamina through direct claims. The calculation of compensation is calculated as the direct loss of fishermen who cannot go to sea during pollution multiplied by the number of fishermen who are registered as members of the Indonesian Fishermen Association (HNSI). The Indonesian Fishermen Association (HNSI) Cilacap Regency requested compensation of Rp. 40.7 billion from PT Pertamina RU IV Cilacap due to an oil leak (Suara Merdeka).

Claims for direct marine pollution compensation by fishermen without the participation of the state are not in accordance with the state's obligations as regulated in the constitutional basis of the 1945 Constitution, Article 33 Paragraph 3 which states that, "the earth and water and the natural resources contained therein are controlled by the state. and used for the greatest prosperity of the people". Oil pollution in the Cilacap Sea leaves many problems, therefore this study seeks to examine the problem of compensation for oil spills at sea as a result of tanker accidents. The fair value of compensation for oil pollution due to tanker accidents needs to be studied in depth considering the function of the sea as a potential natural resource. This research will discuss about Protection of the Sea from Oil Pollution by Tanker Ships in Indonesia.

\section{Result and Discussion}

\section{International Environmental Protection Principles}

The definition of environmental law is related to two aspects, the first is related to the scope of the legal subject and its institutional competence; second, related to responsibility for environmental damage. The 1972 Stockholm Declaration, in Principle 2, states that what is called natural resources on earth are "air, water, land, flora, fauna and natural ecosystems". Meanwhile, European Community law agrees on the environment as the relationship between living things and water, air, land and all biological forms. UNCLOS, as the main source of international maritime law, includes rare or fragile ecosystems and habitats as the scope of protection of the marine environment (Philippe Sands, 2003).

In the context of national law, Law Number 32 of 2009 concerning Environmental Protection and Management (UUPPLH) provides the definition of the environment as a spatial unit with all objects, conditions, and living things, including humans and their behavior, which affect nature itself, the continuity of life, and the welfare of humans and other living creatures. Environmental protection has general principles, namely: 
Sovereignity over natural resources and the responsibility not to cause

damage to the environment of other states or to areas beyond national jurisdiction, as the oldest principle in international law, sovereignty is the main characteristic of a state. A country has internal and external sovereignty. Internal sovereignty means that the state has legislative, executive and judicial jurisdiction over every activity in its territory. The recognition of sovereignty over natural resources was first stated in the UN General Assembly Resolution Number 1803 of 1962 concerning Permanent Sovereignty over Natural Resources. Principle 21 of the Stockholm Declaration states that states, based on the UN Charter and principles of international law, are sovereign to exploit their natural resources and are responsible for ensuring that activities within their jurisdiction or control do not cause environmental harm to other countries or to areas outside the national jurisdiction of a country. . Based on this principle, the state has sovereignty over its territory and carries out activities in its territorial territory. The principle of state sovereignty over its natural resources cannot be separated from the state's obligation to ensure that it does not damage the environment of other countries and the environment in its own jurisdiction.

\section{Principle of preventive action}

Apart from being stated in the 21st Principle of the Stockholm Declaration, the principle of preventive action is also mentioned in the 2nd Principle of the United Nations Conference on Environment and Development (UNCED). This principle has two perspectives. First, this principle requires minimizing environmental damage as the main goal. Second, the state is obliged to prevent environmental damage within and through its jurisdiction, including regulatory, administrative and other measures. Even in the United States of Foreign Affairs Law, it is stated that the state's obligation is not only to take preventive measures, but also to reduce (reduce) and control any environmental losses that occur.

In the case of cross-border pollution, this Principle has two perspectives. First, this principle requires minimizing environmental damage as the main goal. Second, the state is obliged to prevent environmental damage within and through its jurisdiction, including regulatory, administrative and other measures. Even in the United States of Foreign Affairs Law, it is stated that the state's obligation is not only to take preventive measures, but also to reduce (reduce) and control any environmental losses that occur. In the case of cross-border pollution, each country is required to carry out two obligations, first to take the necessary action in good faith; second, to regulate public and private activities which are the subject of its jurisdiction.

\section{Cooperation}

The principle of this cooperation stems from the general principles of good neighborhood which can be found in customary international law and in Article 74 of the UN Charter. This principle is reflected in several international treaties and supported by state practices primarily in hazardous and emergency activities. Cooperation is contained in the 24th Principle of the Stockholm Declaration and the 27th Principle of the Rio Declaration which states that countries must cooperate in the principle of good faith and the spirit of partnership as an effort to protect the environment.

\section{Sustainable development}

The principle of sustainable development emphasizes that development carried out now should not reduce the rights of future generations. In other words, the development must be carried out pay attention to the ability of the environment in meeting the needs of future 
generations. The sustainable principle has several aspects, namely : (1) The need to take into consideration the needs of present and future generation; (2) The acceptance on environment protection grounds, of limit placed upon the use and exploitation of natural resources; (3) The role of equitable principles in the allocation of rights and obligation.

The principle to be used for allocating costs of pollution prevention and control measures to encourage rational use of scarce environmental resource and to avoid distortions in international trade and investment is so called polluter pays principle. That principle means that that polluter should bear the expenses of caring out the above mentioned measures decided by the public authorities to ensure that the environment is in a acceptable states. In other world the cost of these measures should be reflected in the cost of goods and services which cause pollution in production and/or consumption. Such measures should not be accompanied by subsidies that would create significant distortions in international trade and investment.

\section{Precutionary Principle}

In the $15^{\text {th }}$ Rio Declaration Principles has been argued that:

where there are threats of serious or irreversible damage, lack of full scientific certainly shall not be used as areas on for post poning cost effective measures to prevent environmental degradation". That principle means that polluter should bear the expenses of caring out the above mentioned measures decided by the public authorities to ensure that the environment is in a acceptable states. In other world the cost of these measures should be reflected in the cost of goods and services which cause pollution in production and/or consumption. Such measures should not be accompanied by subsidies that would create significant distortions in international trade and investment.

\section{Legal Regulations Governing the Interest of Protection of the Marine Environment from Oil Pollution by Tanker Ships in Indonesia}

National economic development as mandated by the 1945 Constitution of the Republic of Indonesia (UUD'45) is carried out based on the principles of sustainable and environmentally sound development. In addition, the decreasing quality of the environment has threatened the survival of human life and other living creatures, so it is necessary to protect and manage the environment seriously and consistently by all stakeholders. In particular, the mandate of the UUD'45 is spelled out in the weighing section of Law Number 32 of 2009 concerning Protection of Environmental Management (UUPPLH) which states that a good and healthy environment is the basic right of every Indonesian citizen as mandated in Article $28 \mathrm{H}$ of the Law. the constitution of the Republic of Indonesia

Indonesia 1945. This law states that environmental protection and management is a systematic and integrated effort carried out to preserve the functions of the environment and prevent environmental pollution and / or damage which includes planning, utilization, control, maintenance, supervision and law enforcement.

Natural resources in the UUPPLH are mentioned as elements of the environment which consist of biological and non-living resources which as a whole form an integrated ecosystem. Environmental Pollution itself is referred to as the entry or inclusion of living things, substances, energy and / or other components into the environment by human activities so as to exceed the stipulated environmental quality standards. Environmental damage is a direct and / or indirect action against the physical, chemical and / or biological characteristics of the environment that exceeds the standard criteria for environmental damage. Protection and management of the environment in Indonesia as stated in Article 2 UUPPLH is implemented based on the principle; 
state responsibility, sustainability and sustainability, harmony and balance, integration, benefits, prudence, justice, ecoregion, biodiversity, polluter pays, participatory, local wisdom, good governance and regional autonomy.

Environmental protection and management includes; planning, utilization, control, maintenance, supervision and law enforcement. Environmental control in this case is intended to include prevention, mitigation and recovery carried out by the government, regional government and those in charge of businesses and / or activities in accordance with their respective authorities, roles and responsibilities. One of the instruments for preventing pollution and / or environmental damage consists of; environmental economic instruments, environment-based laws and regulations, environment-based budgets and other instruments according to the needs and / or developments of science.

The interesting thing in the UUPPLH is the existence of Article 66 which states that, everyone who is fighting for the right to a good and healthy environment cannot be prosecuted criminally or criminally. This article regulates the participation of the community in obtaining legal protection so that they cannot be prosecuted either criminal or civil when they participate in fighting for the right to a good and healthy environment. The concept of Article 66 is known as the Anti Strategic Lawsuit Against Public Participation (Anti SLAPP). When the SLAPP concept was first published, George W. Pring and Penelope Canan as the founders of this concept divided SLAPP into several fields, including real estate development, taxation, the environment, and others. Especially for SLAPP that occurred in the environmental sector, Pring and Canan popularized the term Eco-SLAPP.

There is no standard definition of SLAPP in the Indonesian legal system. To know the definition of SLAPP, we refer to the definition of the Philippines through the Rules of Procedures for Environmental Cases which give the meaning, among others, a legal action that is proposed to harass, disturb, exert undue pressure or inhibit law enforcement that has been carried out or may be carried out by any person, institution or government in enforcing environmental law, protection of the environment or claims against the right to the environment must be treated as SLAPP and regulated by this regulation. Anti Slapp Advisory Panel Report to The Attorney General in Ontario (Canada) which was adopted in the Protection of Public Participation Act 2013, as stated as an action / lawsuit committed against a person or persons or groups who express opinions or attitudes on related issues with the public interest. SLAPPs use the court system to limit the effectiveness of opposing parties' opinions or actions. SLAPPs can intimidate opponents, drain their resources, reduce opportunities to participate in public affairs and prevent them from participating in matters of public interest. In the elucidation of Article 66 it is stated that this provision is intended to protect victims and / or reporters who take legal means due to environmental pollution and / or destruction. This protection is intended to prevent retaliation from the reported party through criminal punishment and / or civil suit while still paying attention to the independence of the judiciary.

In Law Number 32 of 2014 concerning Maritime Affairs. The term marine as understood through Law Number 32 Year 2014 concerning Marine Affairs, Supplement to the State Gazette of the Republic of Indonesia Number 5605 (Ocean Law), is stated as, "... matters relating to the sea and / or activities in the sea area which include the seabed and the land beneath it, the water column and sea level, including coastal areas and small islands ". Furthermore, the Marine Law states that protection of the marine environment is a systematic and integrated effort to conserve marine resources and prevent pollution and / or environmental damage in the sea which includes marine conservation, marine pollution control, marine disaster management, pollution prevention and control. as well as damage and disaster. Marine administration is carried out based on the principles, sustainability, consistency, integrity, legal certainty, partnership, equity, community participation, openness, decentralization, accountability and justice. The purpose of maritime administration is to utilize marine resources in a sustainable manner for the greatest possible welfare of the current generation without sacrificing the 
interests of future generations, promote marine culture and knowledge for the community, develop human resources in the marine sector who are professional, ethical, dedicated and able to put forward interests nationwide in supporting marine development in an optimal and integrated manner, and providing legal certainty and benefits for all people as an archipelagic country.

Several articles of the Maritime Law provide an understanding of how the state's commitment to its oceans, that the state is fully responsible for protecting its marine environment with the concept of being sustainable and fulfilling justice for present generations and for future generations. In this Marine Law, the protection of the marine environment is the responsibility of the government through controlling marine pollution and preventing and overcoming pollution damage and disasters. Marine disaster in this case is understood as environmental pollution in addition to natural phenomena and global warming. Marine disasters caused by environmental pollution can take the form of oil pollution. More interestingly, the Maritime Law discusses marine pollution in a separate article which, among other things, states that, in anticipating marine pollution, the government establishes policies to mitigate the impacts of marine pollution.

Policies to mitigate the impact of marine pollution can be carried out through the development of a national plan for emergency response to oil spills in the sea, and the development of a marine pollution control system and damage to marine ecosystems. Article 55 Paragraph (1) states that the government and regional governments are obliged to implement a system for preventing and overcoming pollution and damage to the marine environment. Furthermore, in Article 55 Paragraph (1), (2) and (3) which states that the government is responsible for protecting and preserving the marine environment, protection and preservation of the marine environment is carried out through prevention, reduction and control of the marine environment from any marine pollution as well as handling damage to the marine environment, and the government working together, both bilaterally, regionally and multilaterally in implementing prevention, reduction and control.

Protection and preservation of the marine environment is carried out based on the provisions of laws and international maritime law. For marine governance and institutions, Article 69 explains that the government determines marine governance and institutional policies. Marine governance and institutional policies include plans for the development of legal and governance systems as well as systems for planning, coordination, monitoring and evaluation of effective and efficient marine development. In formulating marine governance and institutional policies, the government arranges maritime law in a national legal system through both public and civil aspects by taking into account international law. The interesting thing in the Marine Law is that there is a chapter that regulates community participation, namely Chapter XI, Article 70 which states that, the implementation of marine development is carried out by the government and local governments by involving community participation, community participation can be carried out by individuals, groups, professional organizations. , a business entity or other social organization in accordance with the principles of openness and partnership. Community participation in marine development is carried out through participation in; formulating marine development policies, marine management, marine development and providing input in evaluation and monitoring activities. Community participation can be carried out through participation in preserving cultural values and marine insight and revitalizing customary law and local wisdom in the marine sector, or protecting and disseminating underwater cultural heritage through preservation, restoration and conservation efforts. 


\section{Conclusion}

Environmental control in this case is intended to include prevention, mitigation and recovery carried out by the government, regional government and those in charge of businesses and / or activities in accordance with their respective authorities, roles and responsibilities. One of the instruments for preventing pollution and/or environmental damage consists of; environmental economic instruments, environment-based laws and regulations, environmentbased budgets and other instruments according to the needs and / or developments of science. Policies to mitigate the impact of marine pollution can be carried out through the development of a national plan for emergency response to oil spills in the sea, and the development of a marine pollution control system and damage to marine ecosystems. In Article 55 Paragraph (1) of Law Number 32 Year 2014 concerning Marine Affairs, it is stated that the government and local governments are obliged to implement a system for preventing and overcoming pollution and damage to the marine environment. Furthermore, in Article 55 Paragraph (1), (2) and (3) Law Number 32 Year 2014 concerning Marine Affairs, which states that, the government is responsible for protecting and preserving the marine environment, protection and preservation of the marine environment is carried out through prevention, reduction and control of the marine environment from any marine pollution as well as handling damage to the marine environment, and the government works together, both bilaterally, regionally and multilaterally in implementing prevention, reduction and control.

\section{Reference}

Atmadja, M. K. (1992). Perlindungan dan Pelestarian Lingkungan Laut Dilihat dari Sudut Hukum Internasional, Regional dan Nasional, Jakarta: Sinar Grafika dan Pusat Studi Wawasan Nusantara.

Gayatri R. L, (1999). Demokrasi Pengelolaan Sumber Daya Alam, Prosiding Lokakarya Reformasi Hukum di bidang Pengelolaan Sumber Daya Alam, Cetakan I, ICEL, Pustaka Pelajar Offset.

Gore, A. (1995). Marine Degradation from Land Based Activities: A Global Concern. U.S. Department of States Dispatch, 6(46).

Media Keuangan, Transparansi Informasi Kebijakan Fiskal. (2015). Ekonomi Biru, Harapan Baru Konsep Pembangunan yang Ramah terhadap Alam Potensi menjadi Landasan Program dan Kebijakan di Sektor Maritim.

Republic of The Philippines Supreme Court, Rules of Procedures for Environmental Cases, Section 1 Rule 6.

Sands, P. (2003). Principle of International Environmental Law, Second Edition. Cambridge University Press.

Siahaan, H. R. P. (2018). Ini Data Baru Kewilayahan Laut Indonesia, Gatra.com 10 Agustus 2018, https://www.gatra.com/rubriknasional/337332-Ini-Data-Baru-Kewilayahan-LautIndonesia, Diunduh 10 Agustus 2018, pukul 21.20 WIB.

SLAPPs; Getting Sued for Speaking Out, 1996, Temple University Press, Philadelpia.

Suara Merdeka,29 Mei 2015 3:02 WIB, http://berita.suaramerdeka.com/smcetak/hnsi-tuntutganti-rugi-rp-407-miliar/, diunduh tanggal 5 Maret 2020, Pukul 13.00. WIB.

Triatmodjo, M. (2001). Pengembangan Pengaturan Hukum dan Kelembagaan Pencemaran Laut dari Darat di Kawasan Asia Tenggara. Makalah dalam Hukum dan Lingkungan Hidup Indonesia: 75 Tahun Prof. Dr. Koesnadi Hardjasoemantri, Perpustakaan Nasional: Katalog Dalam Terbitan (KDT) Erman Rajagukguk dan Ridwan Khairandy (Ed), Program Pasca Sarjana Fakultas Hukum Universitas Indonesia. 